\title{
Summary of Modelling Safety Factors of Slope Stability in A Tar-Sand Quarry: A Case Study
}

\author{
Ajibola Rasidat Oyebamiji ${ }^{1{ }^{*}}$, Alao David Afolayan ${ }^{2}$, Mopa Bassagi $^{3}$ and Olarewaju Tajudeen ${ }^{4}$ \\ ${ }^{1}$ Federal University Oye-Ekiti \\ Oye-Ekiti, Nigeria \\ ${ }^{2}$ Global Marble Mining Limited \\ Abuja, Nigeria \\ ${ }^{3}$ University of Ilorin \\ Kwara, Nigeria \\ ${ }^{4}$ Syracruse University \\ New York, USA \\ *Corresponding author's email: ajibola.oyebamiji [AT] fuoye.edu.ng
}

\begin{abstract}
This research studies the importance of slope stability during open-pit mining of tar sand within the Dahomey basin, Southwest Nigeria. It involved the geotechnical characterization of the layers of Laterites and Alluvium which it underlies. In addition, SLOPE/W software of the GeoStudio package was utilized for deducing and modeling the bench face angles which had higher safety factors, through the Morgenstern Price method of slices. It was discovered that the lateritic soil layer possessed higher values of unit weight, cohesion and internal frictional angle than those of the Alluvial Sand layer. Factors of safety were generated for bench face angles ranging from 100 to $90 \mathrm{o}$ at $1 \mathrm{~m}, 4 \mathrm{~m}$ and above $40 \mathrm{~m}$ groundwater levels; over a $10 \mathrm{~m}$ bench width and 6m bench height. However, for heavy equipment, a bench width of $20 \mathrm{~m}$ and height of $6 \mathrm{~m}$ were assumed. This resulted in factors of safety varying between 3.58 and 1.73 for bench face angles between 100 and 300 during higher precipitation (and water tables). Thus, this suggests that stable slopes predominate at bench face angles of $10 \mathrm{o}$ to 300 . This can be further enhanced when sufficient drainage systems are constructed.
\end{abstract}

Keywords- Dahomey Basin, Geotechnical Characterization, Open-Pit Mining, Tar Sand

\section{INTRODUCTION}

The study area, Loda Village, Ondo state (Fig. 1) is located on longitude $4^{\circ} 55^{\prime} \mathrm{E}$ and latitude $6^{\circ} 45^{\prime} \mathrm{N}$ [13] within the Dahomey basin of Southwestern Nigeria (Fig.2) which extends through South-eastern Ghana, Togo, Republic of Benin and Southwestern Nigeria [7]. Tar sand occurs at the eastern parts of the Dahomey basin within the Upper Cretaceous sediments [1, 2, 12,11 and 10]. Ref. [6] and [4] believe the East-West trending tar sand outcrop is about 120km long and $6 \mathrm{~km}$ wide while [3], [5] and [8] estimates the slope angles during its mining at $30^{\circ}$ to $35^{\circ}$ without laboratory analyses, therefore, creating a need for an accurate determination of the geotechnical properties that influence bench face angles employed during slope design. The study is aimed at accurately estimating bench face angles that are stable and safe during mining by geotechnical characterization of the sediments overlying tar sand deposit using a case study within the Southwestern Nigeria. [9] propose safety factors of 1.2 to 1.4 for rock slopes in open-pit mines and higher for soil slopes while [14] explains that more than $40 \%$ of slope failures result from unfavourable groundwater conditions. 


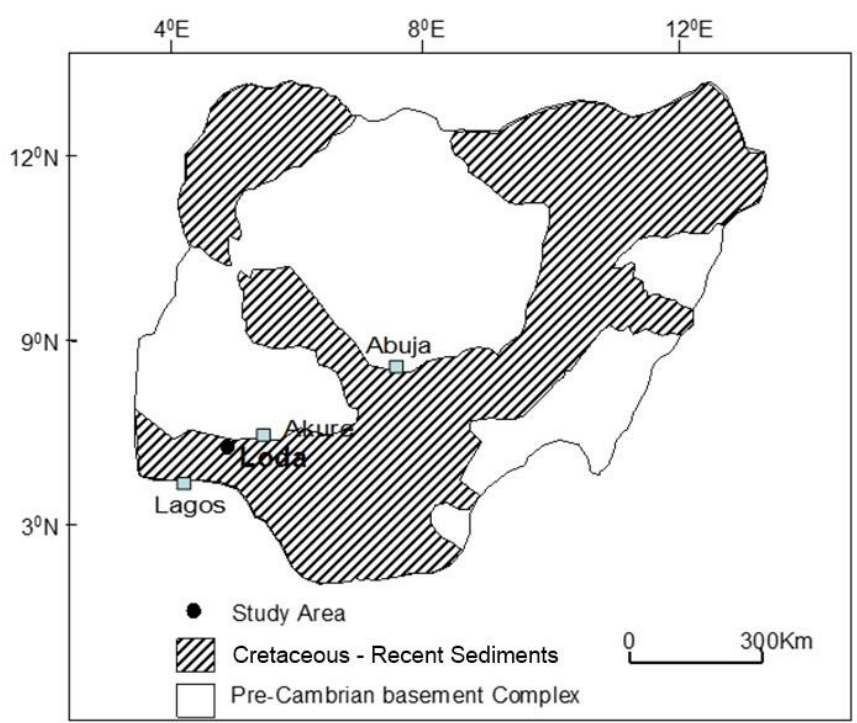

"Figure 1: Map of Nigeria showing the study area, Loda Village, Ondo State Southwestern, Nigeria (modified from Kogbe, 1989)."

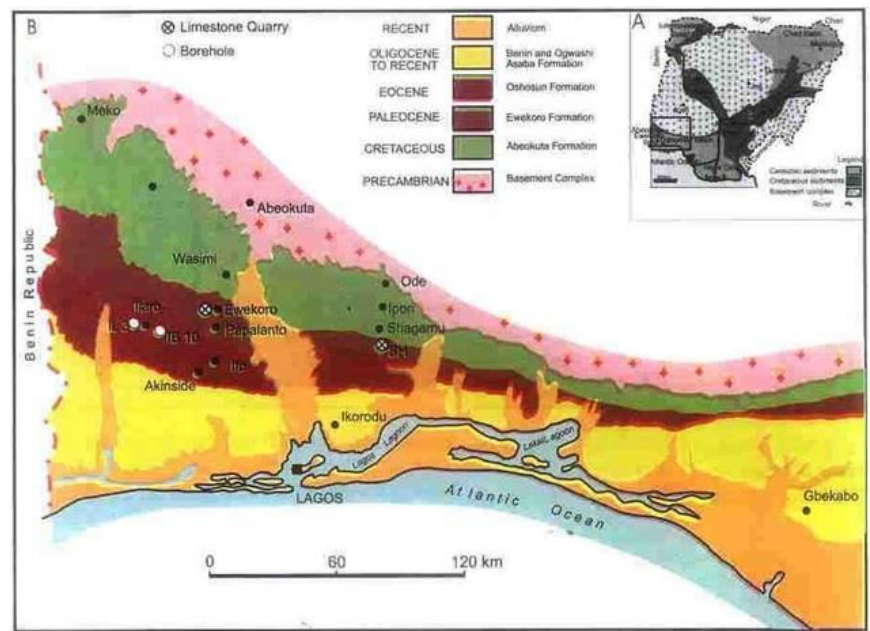

"Figure 2: Map showing part of Nigeria and the study area, Loda Village within the Dahomey Basin (Adapted from Bankole et al., 2006)"

\section{METHODOLOGY}

Primary data were collected from samples taken 200m apart at three locations (L1, L2 and L3) during field mapping along with core drill data obtained from Bitumen Project Implementation Committee (National Agency) and were analysed with results modelled using GeoStudio SLOPE/W software. These samples were collected from the basal parts to the topmost part of the road cut at each location. Graphic sections depicting the lithologies encountered during the mapping are shown in Figures $3 \mathrm{a}$ to $3 \mathrm{c}$. 

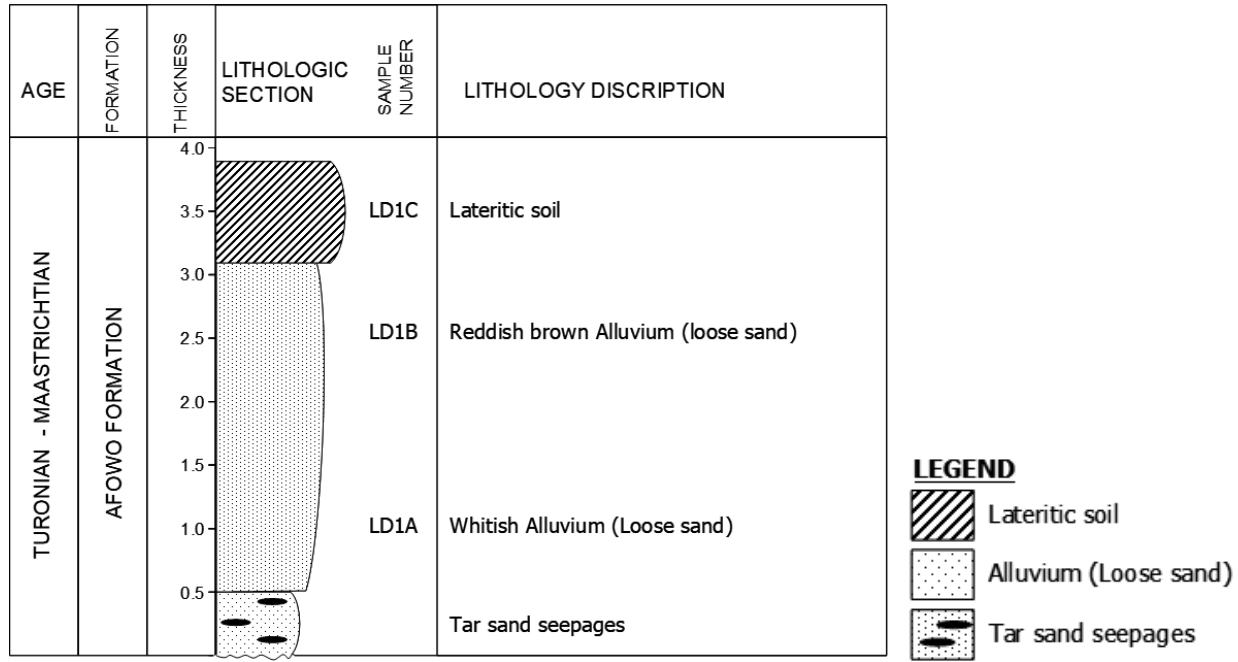

"Figure 3a: Lithologic section of road cut examined at Location 1 (LD 1), Loda Village, Ondo state, Southwestern Nigeria"

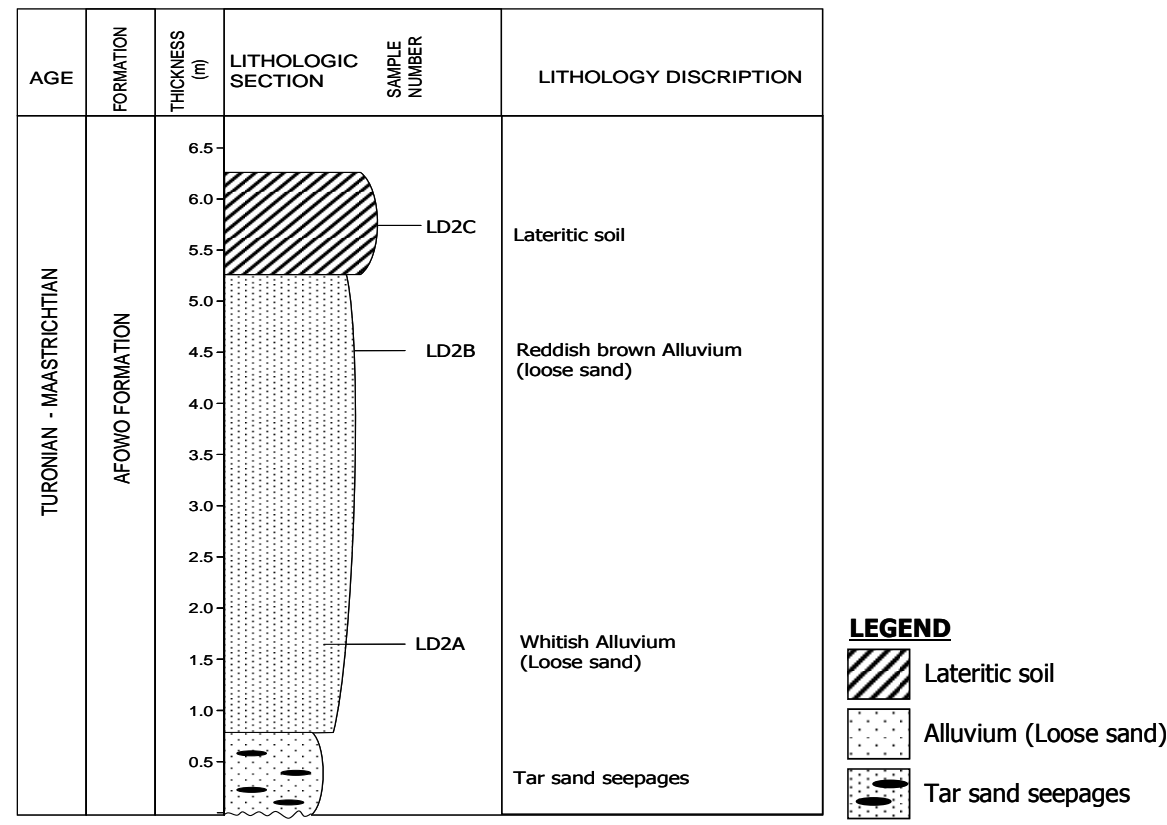

"Figure 3b: Lithologic section of road cut examined at Location 2 (LD 2), Loda Village, Ondo state, Southwestern Nigeria." 


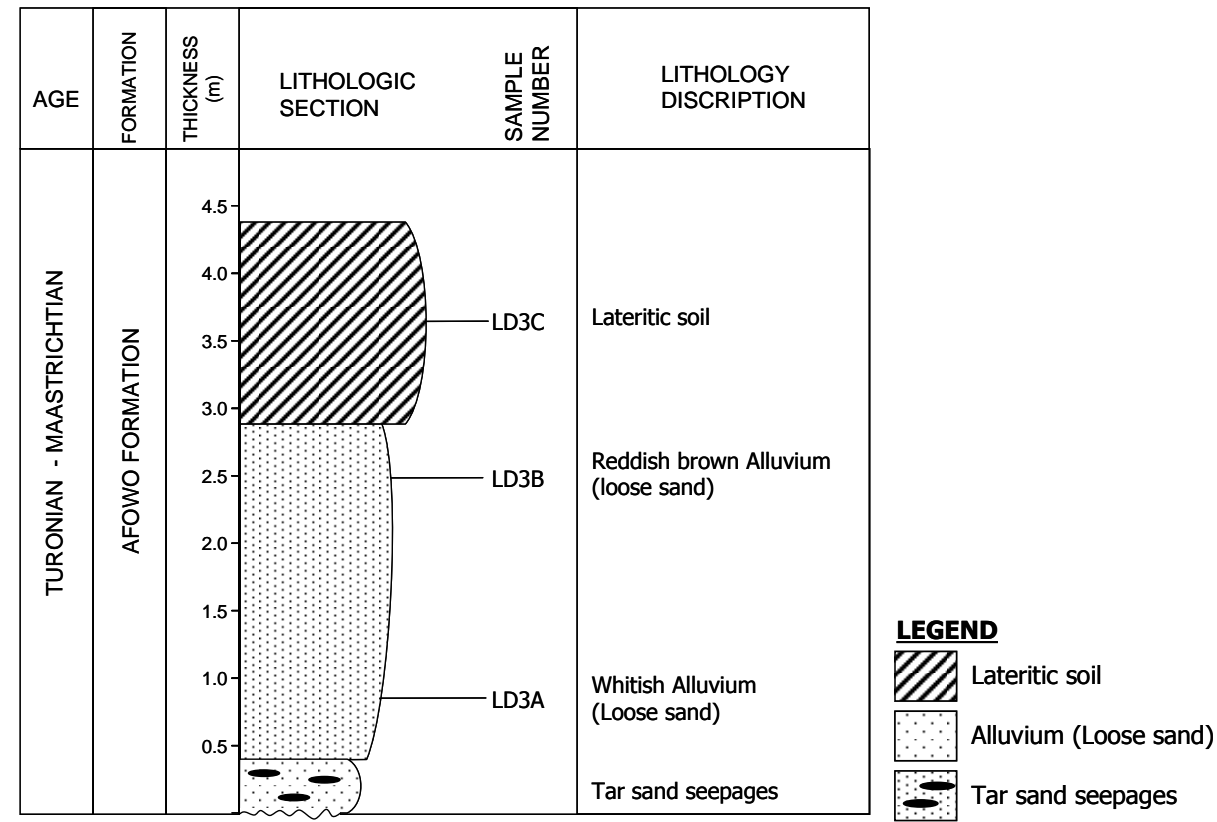

"Figure 3c: Lithologic section of road cut examined at Location 3 (LD 3), Loda Village, Ondo state, Southwestern Nigeria"

The geotechnical characterizations included determining the density of each material, using the density bottle; particle size distribution through mechanical dry sieving methods following BS 1377, 1975; and direct shear tests through the use of the $20 \mathrm{~mm}$ high shear box machine.

During the modeling, hypothetical bench dimension of $10 \mathrm{~m}$ and $20 \mathrm{~m}$ with same height of $6 \mathrm{~m}$ was used while bench face angles were raised from $10^{\circ}$ through to $90^{\circ}$ in order to calculate the safety factors through the Morgenstern Price method. Furthermore, groundwater levels of $1 \mathrm{~m}$ (for wet seasons - May to October, with raised water levels), $4 \mathrm{~m}$ (for dry seasons- November to April) and above 40m were estimated for each bench width attempted and groundwater greatly influences slope stability [14 and 15].

\section{RESULTS AND DISCUSSION}

The geotechnical parameters analysed and inputted into GeoStudio SLOPE/W (Table I) shows that the topmost layer of Laterites has an higher average unit weight of $25 \mathrm{kN} / \mathrm{m}^{3}$, mean cohesion of $45 \mathrm{kPa}$ and internal frictional angle of $41^{\circ}$. However, the underlying layer of Alluvium which is a cohesion-less, loose sand (average cohesion value $=0$ ) has mean unit weight of $18 \mathrm{kN} / \mathrm{m}^{3}$ and internal frictional angle of $34^{\circ}$ which are lower than that of the lateritic topmost layer.

Table 1: Summary of Geotechnical data inputted into the SLOPE/W computer program for the simulation of Factors of safety.

\begin{tabular}{|c|c|c|c|}
\hline & $\begin{array}{c}\text { Average unit } \\
\text { weight values } \\
\left(\mathbf{k N} / \mathbf{m}^{3}\right) \\
\end{array}$ & $\begin{array}{c}\text { Average cohesion } \\
\text { values } \\
(\mathbf{k P a}) \\
\end{array}$ & $\begin{array}{c}\text { Average angle of internal } \\
\text { friction values } \\
\left\{\text { In degrees }\left({ }^{\circ}\right)\right\} \\
\end{array}$ \\
\hline Layer 1 - Lateritic Soil & 25 & 45 & 41 \\
\hline Layer 2 - Alluvium (loose sand) & 18 & 0 & 34 \\
\hline
\end{tabular}

Figure 4 suggests excavation passes at different bench face angles for open-pit mines at the study area, while Figure 5 models safety factors for various groundwater levels at a slope angle of $40^{\circ}$. Tables 2 and 3 reveal that safety factors are higher for deeper groundwater levels that is, slopes are more stable under such conditions. In addition, following [14 and 9], tables II and III show that bench face angles lower than $30^{\circ}$ result in more stable slopes and allow for inundation. 


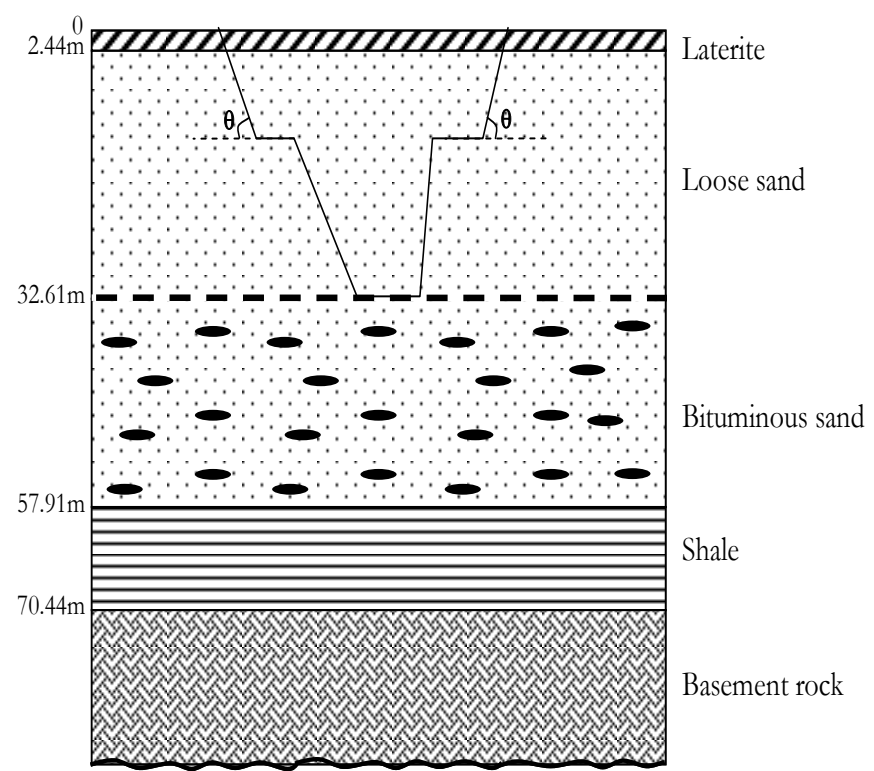

"Figure 4: Diagram showing a pass at slope angle determination and how excavation might occur for an open pit mine using Loda Village southwestern Nigeria as a case study."

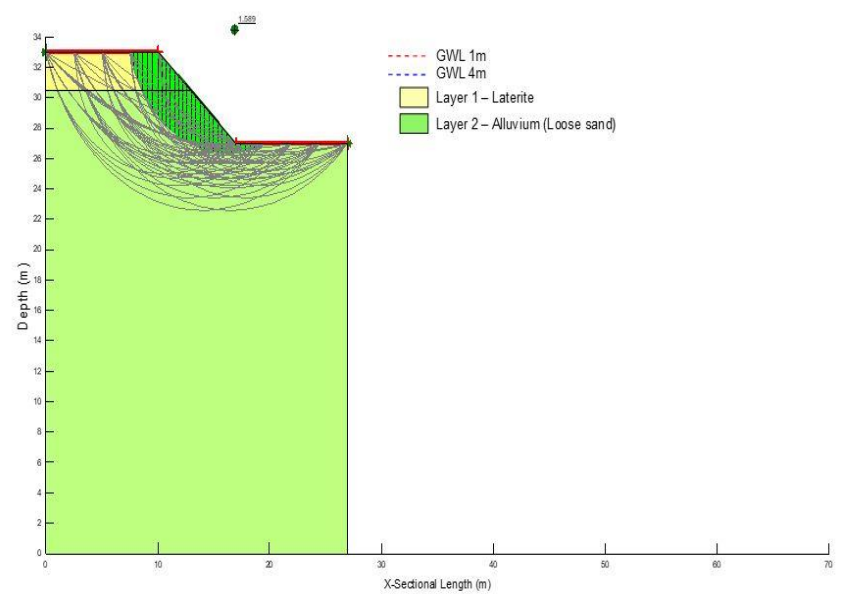

"Figure 5: Simulation of $40^{\circ}$ slope angles to determine the corresponding factors of safety values for different ground water levels using a 10 meters bench and 6 meters bench height."

Table 2: Table showing the factor of safety values obtained from computer simulation using different slope angles for a bench width of 10 metres and bench height of 6 metres cut into the two layers overlying the tar sand deposit at Loda Village, Southwestern Nigeria.

\begin{tabular}{|c|c|c|c|}
\hline $\begin{array}{c}\text { SLOPE ANGLE (IN } \\
\left.\text { DEGREES, }{ }^{\circ}\right)\end{array}$ & \multicolumn{3}{|c|}{ MORGENSTERN-PRICE METHOD OF } \\
& \multicolumn{3}{|c|}{ ANALYSIS } \\
\hline & $\begin{array}{c}1 \mathrm{~m} \\
\text { Piezometric } \\
\text { level }\end{array}$ & $\begin{array}{c}4 \mathrm{~m} \\
\text { Piezometric } \\
\text { level }\end{array}$ & $\begin{array}{c}\text { Very deep } \\
\text { Piezometric level } \\
(>40 \text { metres })\end{array}$ \\
\hline 10 & 3.37 & 3.91 & 4.20 \\
\hline 20 & 2.03 & 2.26 & 2.44 \\
\hline 30 & 1.56 & 1.61 & 1.82 \\
\hline 40 & 1.35 & 1.39 & 1.58 \\
\hline 50 & 1.18 & 1.37 & 1.51 \\
\hline 60 & 1.05 & 1.24 & 1.35 \\
\hline 70 & 0.79 & 1.22 & 1.25 \\
\hline 80 & 0.65 & 1.07 & 1.15 \\
\hline 90 & 0.35 & 1.02 & 1.09 \\
\hline & & \multicolumn{2}{l}{} \\
\hline
\end{tabular}


Table 3: Table showing the factor of safety values obtained from computer simulation using different slope angles for a bench width of 20 metres and bench width of 6metres cut into the two layers overlying the tar sand deposit at Loda Village, Southwestern Nigeria.

\begin{tabular}{|c|c|c|c|}
\hline $\begin{array}{c}\text { SLOPE } \\
\text { ANGLE } \\
\text { (IN }\end{array}$ & \multicolumn{3}{|c|}{$\begin{array}{c}\text { MORGENSTERN-PRICE METHOD } \\
\text { OF ANALYSIS }\end{array}$} \\
\hline & $\begin{array}{c}1 \mathrm{~m} \\
\text { Piezometric } \\
\text { level }\end{array}$ & $\begin{array}{c}4 \mathrm{~m} \\
\text { Piezometric } \\
\text { level }\end{array}$ & $\begin{array}{c}\text { Very deep } \\
\text { Piezometric } \\
\text { level } \\
(>40 \\
\text { metres })\end{array}$ \\
\hline 10 & 3.58 & 4.20 & 4.51 \\
\hline 20 & 2.41 & 2.66 & 2.72 \\
\hline 30 & 1.73 & 1.85 & 2.16 \\
\hline 40 & 1.66 & 1.51 & 1.85 \\
\hline 50 & 1.52 & 1.30 & 1.82 \\
\hline 60 & 1.19 & 1.42 & 1.59 \\
\hline 70 & 0.96 & 1.28 & 1.40 \\
\hline 80 & 0.83 & 1.18 & 1.25 \\
\hline 90 & 0.59 & 1.02 & 1.09 \\
\hline
\end{tabular}

\section{CONCLUSION AND RECOMMENDATION}

In order to assess the slope stability of Tar sand deposit at Loda Village, Ondo state, Southwestern Nigeria, geotechnical analyses was carried out on two lithologies overlying the deposit. The values obtained from the geotechnical analyses were used to simulate the bench face angles of a proposed open-pit mine under different groundwater conditions, with slope angles of $10^{\circ}$ to $30^{\circ}$ being more stable and safer than face angles above $30^{\circ}$.

It is, therefore, recommended that:

- Groundwater pressure should be constantly measured and monitored using appropriate equipment such as piezometers;

- Stability of the slopes should be adequately monitored using state-of-the-art facilities like extensometer (to measure movement) and high-energy pumps (for dewatering);

- Construction of wide trenches and effective drainage systems.

- The use of high-energy submersible pumps for dewatering is necessary when mining commences. 


\section{REFERENCES}

[1] S.O. Adegoke, B.D. Ako, E.I. Enu, S.W. Petters, A.C.W. Adegoke M.O. Odebode, W.O. Emofurieta (1976). Tar sand Project Phase II; Estimation of Reserves, Materials testing and Chemical Analyses. Unpublished report, Geological Consultancy Unit, Department of Geology, University of Ife, Ile-Ife, pp75.

[2] O.S. Adegoke, A.C. Ibe, (1982). The Tar sand and Heavy Crude Resources of Nigeria. Proceedings of the 2nd International Conference on Tar sands and Heavy crude, pp 280-285.

[3] S.O. Adegoke, B.D. Ako, E.I. Enu, S.W. Petters, A.C.W. Adegoke M.O. Odebode, W.O. Emofurieta, (1980). Geotechnical Investigations of the Ondo State Bituminous Sands. Report by the Geological Consultancy Unit, Department of Geology, University of Ife, Ile-Ife, pp25.

[4] D.A. Alao. Nigerian Tar Sands: Potential for direct application in road pavement design and construction. A paper presented at the Southern interdisciplinary round table on African studies (SIRAS) March 30-April1st 2006, Kentucky State University Frankfort Kentucky 40601, USA.

[5] D.A. Alao, M. Bassagi Modeling Safety factors of slope stability in a Tar-sand quarry: A Casey Study 1st Annual Civil Engineering Conference, University of Ilorin Nigeria 26-28 August 2009(p.185+195).

[6] R.D. Adelu, E.A. Fayose (1991, August). Development prospects for the bituminous deposits in Nigeria. In Proceedings 5th UNITAR/UNDP International Conference on Heavy Crude.

[7] S.I. Bankole, E. Schram, B.D. Erdtmann et al. (2006). Palynostratigraphic age and paleo environments of the newly exposed section of the Oshosun formation in the Sagamu Quarry, Dahomey basin SW Nigeria. NAPE Bulletin, $19(2), 25-27$.

[8] M. Bassagi (2007) Computer simulation of slope stability safety factors for tar sand quarrying at Loda Village, Ore Southwestern Nigeria.162p.M.Sc. Thesis submitted to Department of Geology, University of Ilorin. (Unpublished).

[9] C.W. Duncan, C.W. Wyllie (2004). Rock Slope Engineering. 4th edition, spon press, UK. 480p.

[10]E.I. Enu (1985). Textual Characteristics of the Nigerian Tar sands. Sedimentary Geology vol. 44, pp 65-81.

[11]E.I. Enu, O.I.S. Adegoke, C. Robert, B.D. Ako, T.R. Ajayi, Adediran, S.A. A. Oriyomi, (1981). Clay mineral Distribution in the Nigerian tar sand sequence. In: Van Olphen and F. Variable (Eds.). International Clay Conference 1981. Development in Sedimentology, 35. Elsevier Amsterdam, pp 321-323.

[12]H. Gebhardt, O.A. Adekeye, S.O. Akande (2011). Late Paleocene to Initial Eocene Thermal Maximum (IETM) foraminiferal biostratigraphy and paleoecology of the Dahomey basin, southwestern Nigeria. Jahrb. Geol. Bundesanst, 3, 407-419.

[13] C.A Kogbe (Ed.). (1989). Geology of Nigeria. Rock View (Nigeria) Limited.

[14] E.H. Mandzic (1992). Mineral water Risk in Open pit slope Stability. Mine water and the Environment, Vol. Ii No.4, pp 35-42.

[15] W.L. Schroeder, S.E. Dickinson (1996), Soils in Construction, Prentice Hall. 